\title{
Electrocoagulation and Anodic Oxidation as a Complement of Biological Treatment of Sanitary Landfill Leachates
}

\author{
D. Norma, A. Fernandes, L. Ciríaco, M.J. Pacheco* and A. Lopes \\ UMTP and Department of Chemistry, University of Beira Interior, 6201-001 Covilhã, Portugal
}

Received 14 September 2012; accepted 3 December 2012

\begin{abstract}
The electrochemical treatment of leachate samples collected in a Portuguese intermunicipal sanitary landfill was carried out using combined electrocoagulation followed by anodic oxidation processes. Samples were collected after the biological treatment of the in situ plant and in permeate of an ultrafiltration operation, located after the biological treatment. Electrocoagulation was performed with iron consumable anodes, at different initial $\mathrm{pH}$, with and without stirring, at different applied potentials. In the anodic oxidation assays a boron-doped diamond anode was used and applied current densities from 100 to $300 \mathrm{~A} \mathrm{~m}^{-2}$ were tested. The influence of the experimental conditions of the electrocoagulation pretreatment on the anodic oxidation performance was also assessed. In the electrocoagulation assays the lowest iron and energy consumptions per mass of organic load removed were obtained at initial $\mathrm{pH}$ of 4 for the samples collected after the biological treatment and at initial $\mathrm{pH}$ of 6 for the sample collected in the ultrafiltration permeate, all in the unstirred assays. In the anodic oxidation, the highest average current efficiencies were obtained in the assays run at lower current density, being higher for the samples collected after the biological treatment. For both type of samples, the correction of the $\mathrm{pH}$ prior to the electrocoagulation pretreatment led to a decrease in the average current efficiency during the anodic oxidation.
\end{abstract}

Keywords: landfill leachate; electrocoagulation; anodic oxidation; BDD.

\section{Introduction}

Sanitary landfill is the most common municipal solid waste disposal method due to its relatively simple procedure and low cost. However, leachates produced by the percolation of rain water through the landfill are inevitable and a source of pollution for the environment [1-5].

\footnotetext{
* Corresponding author. E-mail: mjap@ubi.pt
} 
An integrated approach to control the environmental impacts of certain industrial activities (including sanitary landfill), preventing the release of harmful substances to the ambient, is described in the Integrated Pollution Prevention and Control (IPPC) document [http://www.environment-agency.gov.uk]. In order to observe this regulatory procedure, it is important to make the characterisation of leachates and a selection of appropriate treatment processes $[3,6]$.

Leachates are dark coloured liquid suspensions, characterized by very high values of organic and inorganic loads, nitrogen compounds and suspended and dissolved solids. The most common treatments for sanitary landfill leachates are physical/chemical methods followed by biological processes. However, even after biological treatments, those parameters remain very high [5,7], because some of the pollutants are refractory, preventing their effective removal during biological treatments. Thus, post-biological treatments are needed, to remove contaminants or to improve leachates biodegradability. Recently, ultrafiltration has been used in some integrated treatment of leachates from municipal sanitary landfill. Although this unit operation leads to a significant decrease in permeate pollutants load, it is an expensive treatment, especially when nanofiltration or reverse osmosis are involved [8-10].

Electrocoagulation (EC) is an electrochemical method that is also frequently applied to remove organic matter. EC is a very complex chemical and physical operation that uses sacrificial anodes and leads to a sludge of precipitated complexes formed by the anode ion hydroxides and the organic compounds in solution or suspension. The main processes that take place in the electrolytic system when iron anodes are used can be described by reactions (1) to (4) [11].

Anode: $\quad \mathrm{Fe}_{(\mathrm{s})} \rightarrow \mathrm{Fe}^{2+}{ }_{(\mathrm{aq})}+2 \mathrm{e}^{-}$

Cathode: $\quad 2 \mathrm{H}_{(\mathrm{aq})}^{+}+2 \mathrm{e}^{-} \rightarrow \mathrm{H}_{2(\mathrm{~g})} \quad$ (acidic medium)

$$
2 \mathrm{H}_{2} \mathrm{O}_{(\mathrm{l})}+2 \mathrm{e}^{-} \rightarrow 2 \mathrm{OH}_{(\mathrm{aq})}^{-}+\mathrm{H}_{2(\mathrm{~g})} \quad \text { (alkaline medium) }
$$

In solution: $\quad \mathrm{Fe}^{2+}{ }_{(\mathrm{aq})}+2 \mathrm{OH}^{-}{ }_{(\mathrm{aq})} \rightarrow \mathrm{Fe}(\mathrm{OH})_{2(\mathrm{~s})}$

$\mathrm{Fe}^{3+}$ ions may also be present and, depending on the $\mathrm{pH}$, different insoluble hydroxide mononuclear complexes may be formed. The $\mathrm{Fe}(\mathrm{OH})_{2}$ and $\mathrm{Fe}(\mathrm{OH})_{3}$ flocs have strong affinity for colloids, dispersed particles and ionic species and cause flocculation, which generates bigger particles. The formed flocs can be removed by sedimentation or flotation $[11,12]$. The generation of metallic ions by EC is very dependent on the applied potential and on the characteristics of the wastewater, namely, the $\mathrm{pH}$ and the conductivity [13]. Electrocoagulation studies performed with leachates lead to good chemical oxygen demand (COD) removals $[14,15]$.

Oxidative advanced processes, like anodic oxidation (AO), can also be used to eliminate refractory pollutants, and several combination of methods including AO were already tested in the treatment of landfill leachates: before or after biological treatment and in the permeate of membrane treatment; with raw leachate or with diluted samples; using different type of anodes, like noble metals, metal oxides and boron-doped diamond (BDD) [7, 9,16-32]. 
The electrochemical methods can also be used in sequential processes. Ihara and collaborators performed a combined process of electrocoagulation with iron anodes and electrochemical oxidation with $\mathrm{Ti} / \mathrm{PbO}_{2}$ to treat leachates: in the EC step, besides COD reduction, phosphorus was removed with good yield and, in the second step, oxidation with $\mathrm{PbO}_{2}$, the remaining $\mathrm{COD}$ and ammonium nitrogen were almost completely removed [33].

Other studies reported in literature refer combined methods to treat landfill leachates: biochemical treatment and electrochemical oxidation with a BDD anode, in independent, sequential or simultaneous treatments, being the best TOC removal obtained in the simultaneous treatment, pointing to a synergetic effect that conduces also to an increase in biodegradability and a decrease in toxicity indexes [7]; membrane bioreactor combined with anodic oxidation, using a Ti/Pt electrode, where very good removals in COD were obtained [9].

The aim of this work was to evaluate the application of sequential electrocoagulation and anodic oxidation to complement the in situ biological treatment of sanitary landfill leachates. Samples were collected in an intermunicipal landfill that possesses an ultrafiltration operation after the biological treatment, being the collecting points at the end of the biological treatment and in the ultrafiltration permeate. The electrocoagulation was used as a first step, in order to remove colloidal and suspended particles and the anodic oxidation was used after that to eliminate the remaining dissolved organic pollutants. In the electrocoagulation assays, different experimental conditions were tested, in order to study their influence on the removal of organic matter, namely, initial $\mathrm{pH}$ of the samples that was varied in the ideal $\mathrm{pH}$ range for the application of electrocoagulation technique [11], the existence of stirring, and the applied potential. Anodic oxidation assays were performed at different applied current densities in samples subjected to an electrocoagulation pre-treatment.

\section{Materials and methods \\ Leachate samples}

The leachate samples used in this study were collected in two different seasons of the year, at the beginning of summer (L1) and at the beginning of winter (L2). In both seasons, enough leachate to perform all the assays was collected $(25 \mathrm{~L}$ of each type of sample) and kept refrigerated, in order to maintain its initial characteristics. For each season, two different kinds of samples were collected: one after biological treatment $(\mathrm{AB})$ and the other in the ultrafiltration permeate (UP).

\section{Analytical determinations}

The samples collected at the leachate treatment plant and those from the electrochemical assays were analyzed for the following parameters: Chemical oxygen demand (COD), using close reflux dichromate titrimetric method; Dissolved solids (DS) and Suspended solids (SS), determined according to standard procedures [25]; Total organic carbon (TOC) or dissolved organic 
carbon (DOC) (determined after filtration), measured using a TOC analyser, Shimadzu TOC-V CSH. UV-Visible absorption spectrophotometric analyses, with absorbance (Abs) measured from 200 to $800 \mathrm{~nm}$, were also done, using a Shimatzu UV-1800 spectrophotometer. Measurements of $\mathrm{pH}$ and conductivity were carried out with a Mettler-Toledo $\mathrm{pH}$-meter and a Mettler-Toledo conductimeter, respectively.

\section{Electrochemical assays}

The cell used in EC study, with $250 \mathrm{~mL}$ useful volume, contained an iron anode, with an immersed area of $20 \mathrm{~cm}^{2}$, and a stainless steel cathode of $16 \mathrm{~cm}^{2}$, being the distance between them of $2.3 \mathrm{~cm}$. Experiments were conducted in batch mode, with $150 \mathrm{~mL}$ of raw sample.

With the aim of optimizing experimental conditions, for L1 samples, at natural $\mathrm{pH}$ (AB-8.1; UP-8.0), different applied potential differences were tested, between 2 and $6 \mathrm{~V}$. For samples L2, several different initial $\mathrm{pH}$ conditions were also studied, namely, natural $\mathrm{pH}$ (AB-7.8; UP-7.4), $\mathrm{pH} 4,6$ and 10, with applied voltages between 4 and $6 \mathrm{~V}$. All $\mathrm{pH}$ adjustments were done by the addition of concentrated $\mathrm{NaOH}$ or $\mathrm{H}_{2} \mathrm{SO}_{4}$ solutions. To study the effect of mixing in the process efficiency, all the experimental conditions mentioned above were tested without and with stirring $(600 \mathrm{rpm})$. After various elapsed times, the electrocoagulated samples started to precipitate. When massive precipitation was no longer observed (10 to 50 minutes after starting the assay), current was turned off and the treated effluent was allowed to settle for $30 \mathrm{~min}$ and then the supernatant liquid was collected for the analytical determinations. All the assays were run at least twice. When COD (or DOC) removals of both assays differ from more than $10 \%$, assays were repeated, thus guaranteeing that standard deviations of the results presented for these parameters are less than or equal to $10 \%$. The results presented are the mean values of all the experiments performed. Between experiments, the electrodes were washed, first with tap water and then with distilled water, to remove the sludge adsorbed on the electrode surface.

The combined treatment, electrocoagulation followed by anodic oxidation (AO), was performed with $450 \mathrm{~mL}$ of leachate at the following electrocoagulation conditions: natural $\mathrm{pH}$, without stirring, for L1 samples; $\mathrm{pH} 6$ and natural, without stirring, for L2 samples. This procedure was repeated until enough volume to perform the anodic oxidations was obtained. After 1 hour EC pretreatment, the suspension was allowed to settle, decanted and subjected to filtration, in order to eliminate most of the suspended matter from the liquid mixture, thus avoiding the unnecessary energy consume that would be used in the anodic oxidation of the organic matter present in the smaller flocs. The filtrate was then subjected to the anodic oxidation treatment.

AO experiments were conducted in a $300 \mathrm{~mL}$ cell, in batch mode, for $8 \mathrm{~h}$, with imposed current density of 100, 200 and $300 \mathrm{~A} \mathrm{~m}^{-2}$, using $200 \mathrm{~mL}$ of the electrocoagulated effluent. A BDD anode, with an immersed area of $20 \mathrm{~cm}^{2}$, and a stainless steel cathode, with identical area, were used and the distance between them was $2 \mathrm{~cm}$. 
In EC and AO, a GW, Lab DC, model GPS-3030D (0 30V, 0 3A), was used as power supply. Experiments were conducted at room temperature $\left(22-25{ }^{\circ} \mathrm{C}\right)$, without addition of background electrolyte and samples were collected regularly, to perform the analytical determinations. AO experiments were repeated twice and the values presented are the mean of the results obtained. COD standard deviations for the samples collected in both assays, hourly, were calculated and they were always lower than 5\%. Between experiments, the cell was cleaned with a $\mathrm{NaCl}$ solution $0.1 \mathrm{M}$, for $10 \mathrm{~min}$, using an applied current density of 300 $\mathrm{A} \mathrm{m}^{-2}$, and rinsed with $3 \times 500 \mathrm{~mL}$ of distilled water.

\section{Results and discussion}

\section{Samples characterization}

Table 1 presents the characteristics of the leachate samples collected at a Portuguese sanitary landfill plant, located in the region of Beira Interior, in two different seasons of the year. Although COD does not seem to be dependent on the season, the dissolved organic carbon is lower for the sample collected at the wet season (L2), probably due to a dilution effect, since COD is determined in the whole sample and DOC in the filtrate. Dilution effect may also explain lower suspended solids and higher dissolved solids for L2 samples. These samples also present lower $\mathrm{pH}$ and conductivity than $\mathrm{L} 1$ samples. In the case of $\mathrm{AB}$ samples, the sum of SS and DS is similar for both seasons. However, in the case of UP that sum is very different, probably due to variations in the type of membrane used in the ultrafiltration process.

Table 1. Characterization of the samples collected at different places in the landfill leachate treatment plant, in different seasons of the year.

\begin{tabular}{cccccccc}
\hline \multirow{2}{*}{ Sample } & $\begin{array}{c}\mathbf{C O D} / \\
\mathbf{g ~ L}^{-\mathbf{1}}\end{array}$ & $\begin{array}{c}\mathbf{D O C} / \\
\mathbf{g ~ L}^{-\mathbf{1}}\end{array}$ & $\begin{array}{c}\mathbf{S S ~ /} \\
\mathbf{g ~ L}^{-\mathbf{1}}\end{array}$ & $\begin{array}{c}\mathbf{D S} / \\
\mathbf{g ~ L}^{-\mathbf{1}}\end{array}$ & $\mathbf{p H}$ & $\begin{array}{c}\text { Conductivity } \\
/ \mathbf{~ m S ~ c m}^{-1}\end{array}$ \\
\hline \multirow{2}{*}{$\mathrm{L} 1$} & $\mathrm{AB}$ & $11.72 \pm 0.09$ & $2.11 \pm 0.02$ & $5.70 \pm 0.40$ & $19.5 \pm 2.3$ & 8.1 & 30.4 \\
& $\mathrm{UP}$ & $3.44 \pm 0.02$ & $1.19 \pm 0.02$ & $0.36 \pm 0.09$ & $17.4 \pm 1.2$ & 8.0 & 25.9 \\
\hline \multirow{2}{*}{$\mathrm{L} 2$} & $\mathrm{AB}$ & $11.60 \pm 0.22$ & $1.83 \pm 0.03$ & $2.37 \pm 0.32$ & $24.3 \pm 0.9$ & 7.8 & 24.0 \\
& $\mathrm{UP}$ & $3.20 \pm 0.20$ & $1.04 \pm 0.03$ & $0.49 \pm 0.13$ & $26.2 \pm 0.3$ & 7.4 & 24.4 \\
\hline
\end{tabular}

\section{Electrocoagulation assays}

Table 2 presents the results obtained in the electrocoagulation assays of samples $\mathrm{L} 1$ and $\mathrm{L} 2$, at natural initial $\mathrm{pH}$, with applied potentials of 4, 5 and $6 \mathrm{~V}$, with and without stirring. The results obtained at applied potentials of 2 and $3 \mathrm{~V}$ are not shown, since it was not observed significant coagulation or flocculation, even after $1 \mathrm{~h}$ assay. The specific iron consumption, $\mathrm{Fe}_{\mathrm{sp}}$, in $\mathrm{g} \mathrm{L}^{-1}$, resulting from the oxidation of the anode, and the specific energy consumption, $\mathrm{E}_{\mathrm{sp}}$, in $\mathrm{W} \mathrm{h} \mathrm{L} \mathrm{L}^{-1}$, were calculated according to the following equations:

$$
\mathrm{Fe}_{\mathrm{sp}}=\frac{\mathrm{It} \mathrm{M}_{\mathrm{Fe}}}{\mathrm{FnV}}
$$




$$
\mathrm{E}_{\mathrm{sp}}=\frac{\mathrm{E} \mathrm{It}}{3600 \mathrm{~V}}
$$

where $\mathrm{I}$ is the current intensity, in $\mathrm{A}, \mathrm{t}$ is the electrocoagulation time, in $\mathrm{s}, \mathrm{M}_{\mathrm{Fe}}$ is the iron molar mass, in $\mathrm{g} \mathrm{mol}^{-1}, \mathrm{~F}$ is the Faraday constant, in $\mathrm{C} \mathrm{mol}^{-1}, \mathrm{n}$ is the number of electrons involved in the oxidation of $\mathrm{Fe}$ to $\mathrm{Fe}^{2+}, \mathrm{V}$ is the volume of the sample, in $\mathrm{L}$, and $\mathrm{E}$ is the applied potential in $\mathrm{V}$.

Table 2. Experimental results for leachate samples collected in different seasons of the year, L1 and L2, after the biological treatment and in the ultrafiltration permeate, subjected to electrocoagulation with iron anodes, at initial natural $\mathrm{pH}$, performed with and without stirring and at different applied potentials.

\begin{tabular}{|c|c|c|c|c|c|c|c|c|c|c|c|c|}
\hline \multirow{4}{*}{\begin{tabular}{l}
\multicolumn{1}{c}{ L1 } \\
Assay number \\
Stirring \\
E / V
\end{tabular}} & \multicolumn{6}{|c|}{ After Biological Treatment } & \multicolumn{6}{|c|}{ Ultrafiltration Permeate } \\
\hline & $\mathrm{A} 1$ & A2 & $\mathrm{A} 3$ & A4 & A5 & A6 & B1 & $\mathrm{B} 2$ & B3 & B4 & B5 & B6 \\
\hline & \multicolumn{3}{|c|}{ stirred } & \multicolumn{3}{|c|}{ unstirred } & \multicolumn{3}{|c|}{ stirred } & \multicolumn{3}{|c|}{ unstirred } \\
\hline & 4 & 5 & 6 & 4 & 5 & 6 & 4 & 5 & 6 & 4 & 5 & 6 \\
\hline ECtime / min & 30 & 30 & 20 & 30 & 25 & 20 & 40 & 40 & 40 & 30 & 20 & 10 \\
\hline $\mathrm{Fe}_{\mathrm{sp}} / \mathrm{g} \mathrm{L}^{-1}$ & 1.67 & 1.98 & 1.78 & 1.31 & 1.50 & 1.06 & 2.23 & 3.85 & 5.48 & 1.28 & 1.22 & 0.96 \\
\hline $\mathrm{E}_{\mathrm{sp}} / \mathrm{Wh} \mathrm{L}^{-1}$ & 6.4 & 9.5 & 10.3 & 5.0 & 6.3 & 6.1 & 8.7 & 18.8 & 32.0 & 5.0 & 6.0 & 5.6 \\
\hline $\mathrm{COD} / \mathrm{COD}_{0}$ & 0.41 & 0.42 & 0.41 & 0.53 & 0.41 & 0.42 & 0.66 & 0.63 & 0.58 & 0.71 & 0.72 & 0.73 \\
\hline $\mathrm{DOC} \mathrm{DOC}_{0}$ & 0.76 & 0.81 & 0.77 & 0.75 & 0.81 & 0.79 & 0.62 & 0.63 & 0.60 & 0.66 & 0.64 & 0.67 \\
\hline $\mathrm{DS} / \mathrm{DS}_{0}$ & 1.07 & 1.10 & 1.06 & 1.08 & 1.03 & 1.05 & 0.96 & 1.00 & 1.00 & 0.99 & 1.04 & 1.07 \\
\hline $\mathrm{C}^{*} / \mathrm{C}_{0}$ & 0.74 & 0.82 & 0.85 & 0.89 & 0.92 & 1.0 & 0.89 & 0.93 & 0.99 & 0.85 & 0.74 & 0.87 \\
\hline $\mathrm{pH}$ final ${ }^{* *}$ & 9.7 & 9.7 & 9.6 & 9.8 & 9.7 & 9.8 & 9.4 & 9.4 & 9.5 & 9.5 & 9.5 & 9.5 \\
\hline \multicolumn{7}{|c|}{ cal Treatment } & \multicolumn{6}{|c|}{ Ultrafiltration Permeate } \\
\hline Assay number & $\mathrm{C} 1$ & $\mathrm{C} 2$ & $\mathrm{C} 3$ & $\mathrm{C} 4$ & $\mathrm{C} 5$ & C6 & D1 & D2 & D3 & D4 & D5 & D6 \\
\hline Stirring & \multicolumn{3}{|c|}{ stirred } & \multicolumn{3}{|c|}{ unstirred } & \multicolumn{3}{|c|}{ stirred } & \multicolumn{3}{|c|}{ unstirred } \\
\hline $\mathrm{E} / \mathrm{V}$ & 4 & 5 & 6 & 4 & 5 & 6 & 4 & 5 & 6 & 4 & 5 & 6 \\
\hline ECtime / min & 20 & 20 & 20 & 30 & 20 & 20 & 20 & 20 & 20 & 20 & 10 & 10 \\
\hline $\mathrm{Fe}_{\mathrm{sp}} / \mathrm{g} \mathrm{L}^{-1}$ & 1.63 & 1.48 & 1.70 & 1.52 & 1.35 & 1.79 & 1.04 & 1.40 & 1.44 & 1.29 & 0.89 & 0.89 \\
\hline $\mathrm{E}_{\mathrm{sp}} / \mathrm{Wh} \mathrm{L}^{-1}$ & 6.3 & 7.1 & 9.8 & 5.8 & 6.5 & 10.3 & 4.0 & 6.7 & 8.3 & 4.9 & 4.3 & 5.1 \\
\hline $\mathrm{COD} / \mathrm{COD}_{0}$ & 0.70 & 0.75 & 0.72 & 0.70 & 0.74 & 0.67 & 0.78 & 0.73 & 0.71 & 0.75 & 0.95 & 0.82 \\
\hline $\mathrm{DOC} \mathrm{DOC}_{0}$ & 0.65 & 0.68 & 0.67 & 0.73 & 0.70 & 0.73 & 0.76 & 0.85 & 0.72 & 0.84 & 0.83 & 0.85 \\
\hline $\mathrm{DS} / \mathrm{DS}_{0}$ & 0.95 & 0.92 & 0.94 & 0.94 & 0.93 & 0.92 & 0.71 & 0.68 & 0.65 & 0.69 & 0.69 & 0.71 \\
\hline $\mathrm{C}^{*} / \mathrm{C}_{0}$ & 1.24 & 1.16 & 1.06 & 1.17 & 1.10 & 1.12 & 1.43 & 1.21 & 1.10 & 1.52 & 1.26 & 1.13 \\
\hline $\mathrm{pH}$ final** & 9.6 & 9.5 & 9.4 & 9.5 & 9.6 & 9.5 & 9.7 & 9.6 & 9.8 & 9.3 & 9.3 & 9.3 \\
\hline
\end{tabular}

Results presented in Table 2 show that, for L1 or L2 samples collected after biological treatment, stirring did not have a marked influence on COD or DOC removals. However, in the assays performed without stirring similar removals were obtained with lower iron and energy consumptions. This effect is even more obvious with UP samples, where stirring in most of the cases slightly increases COD and DOC removals with very high increases in iron and energy consumptions, being the only exception assay D4. Apparently, stirring destroys the aggregates, preventing their precipitation. The EC treatment performed shows much higher reductions in COD and DOC for L1 samples, with a slightly increase in DS, meanwhile a reduction in DS is observed for L2 samples. Regarding $\mathrm{pH}$, similar increases were observed for all samples and experimental conditions. For samples L1, with much higher initial conductivity than samples L2, there was a reduction in this parameter during electrocoagulation. On the other hand, there was an increase in conductivity during treatment for samples 
L2, particularly for UP samples. The higher conductivities presented by samples L2 after treatment, when compared with samples L1, can not be explained with the iron consumption, that is even lower for most of L2 assays, as well as energy consumptions. However, COD removals were much higher for L2 samples, meaning that at the end of the treatment the suspension was "cleaner", with less humic matter, thus with higher conductivity.

Table 3. Experimental results for the leachate samples L2, collected after the biological treatment and in the ultrafiltration permeate, subjected to electrocoagulation assays with iron anodes, performed in different experimental conditions: with and without stirring, at several initial $\mathrm{pH}$ and at various applied potentials.

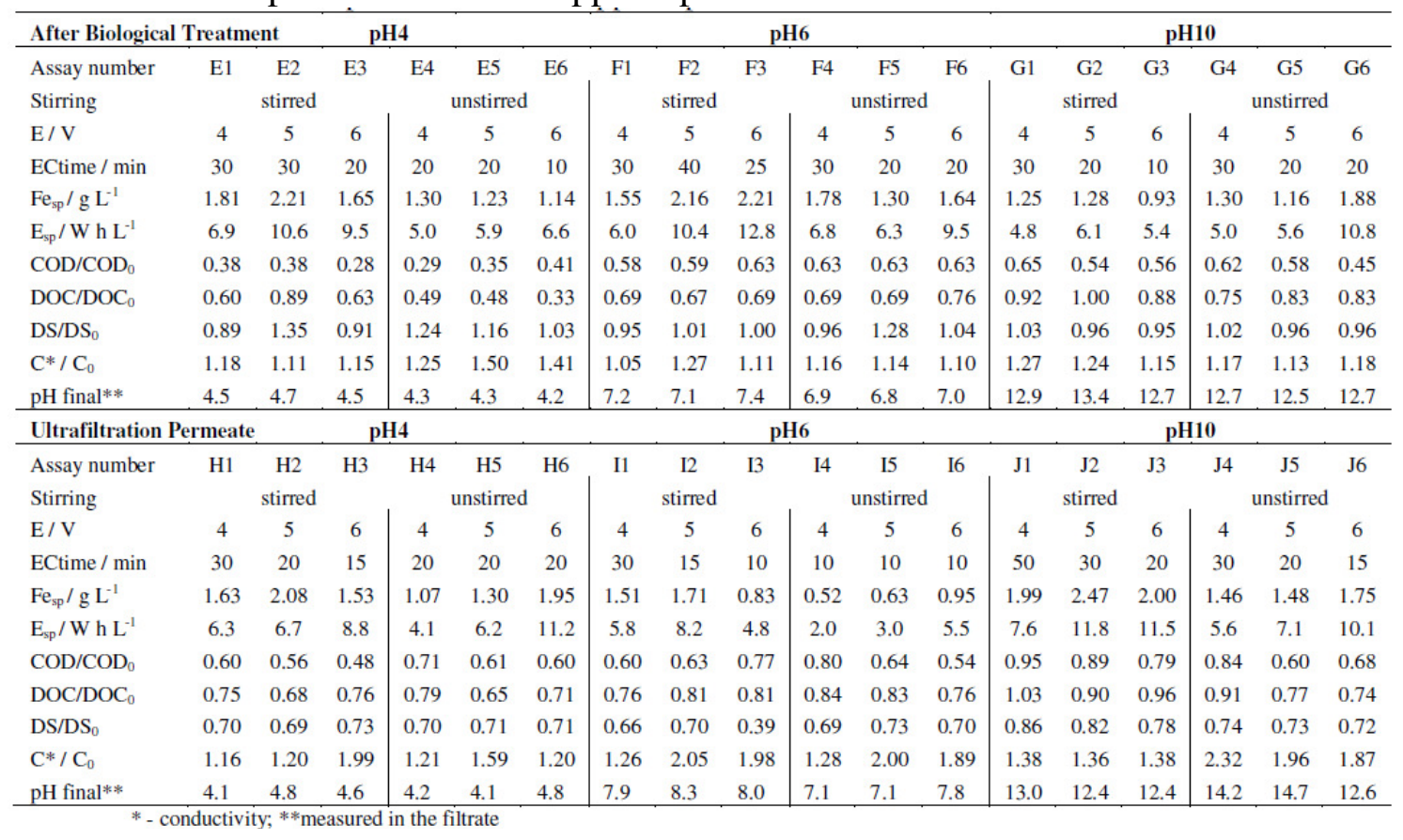

The results obtained in the electrocoagulation treatment performed with $\mathrm{L} 2 \mathrm{AB}$ samples at different initial $\mathrm{pH}$ (Tables 2 and 3, assays $\mathrm{C}, \mathrm{E}, \mathrm{F}$ and $\mathrm{G}$ ) indicate that stirring has little effect in COD and DOC removals.

Regarding iron and energy consumption, if G6 assay is excluded, the lower consumes at identical stirring and applied potential conditions were obtained for the initial $\mathrm{pH}$ of 10. In conclusion, about the assays performed with L2 samples collected after the biological treatment it seems that initial $\mathrm{pH}$ of 4 gives the highest load removals, with final solutions presenting a $\mathrm{pH}$ around 4 in the filtrate, with an increase in conductivity, especially in the unstirred assays. Although lower energy and iron consumptions were obtained for the samples with initial $\mathrm{pH} 10$, those assays led to lower organic load removals with very high final $\mathrm{pH}$ in the filtrates.

The results for the assays run with UP samples at different initial $\mathrm{pH}$ can be compared consulting Tables 2 and 3, assays D, H, I and J. In the case of the assays run at natural initial $\mathrm{pH}$ of 7.4, without stirring, reductions in DS are, in general, more similar to $\mathrm{COD}$ and $\mathrm{DOC}$ removals than in the case of $\mathrm{AB}$ samples, indicating that the matter removal took place mainly by a mechanism of precipitation. 
For the assays run at initial $\mathrm{pH}$ of 4 , the COD removal increases with the applied potential and, for the same applied potential, it increases with stirring. For this $\mathrm{pH}$, the removals in DOC were always lower than that of COD. For the initial $\mathrm{pH}$ of 6 , the stirred assays presented higher COD and DOC removals, being for all the assays, with and without stirring, the COD removals higher than those of DOC. In fact, this is the general behaviour for the UP samples, no matter the initial $\mathrm{pH}$. This is the most regular behaviour and it was not a constant in samples $A B$ probably due to the insoluble organic matter, as was already pointed out. However, since the UP samples present less suspended matter, the determinations of COD, in the suspension, and DOC, in the filtrate, present a better agreement among them than the results observed for $\mathrm{AB}$ samples.
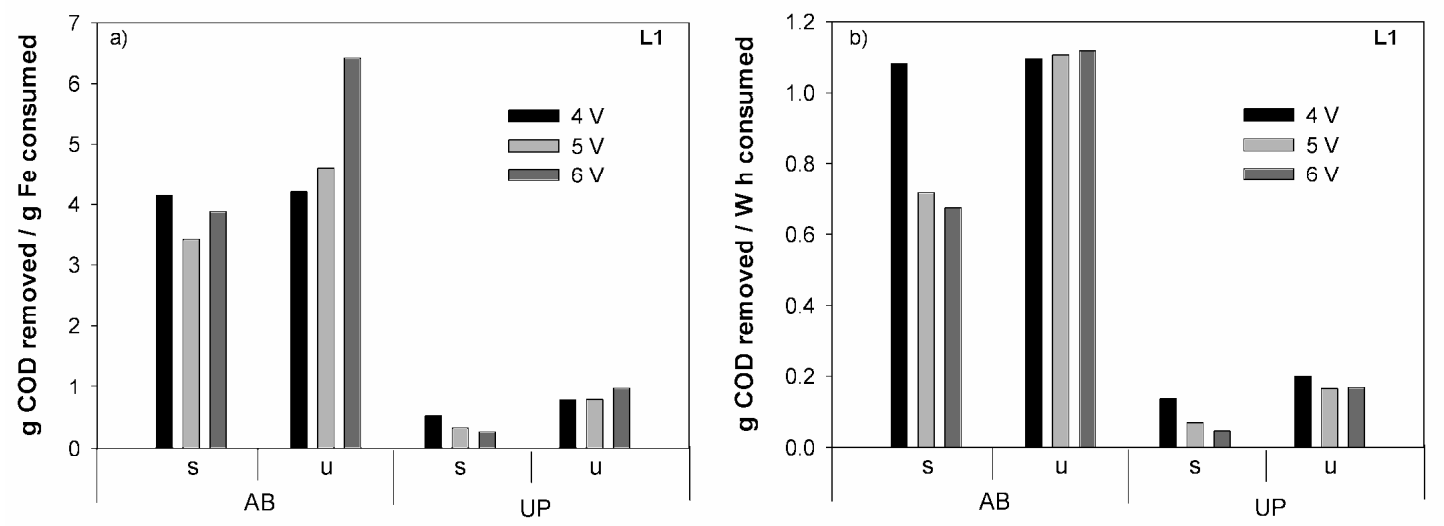

Figure 1. Ratios of COD removed by iron (a) and energy (b) consumption for the electrocoagulation assays performed with leachate L1, with the samples collected after biological treatment (AB) and in ultrafiltration permeate (UP), at natural initial $\mathrm{pH}$ and different applied potentials.

In the assays run at the initial $\mathrm{pH}$ of 10 , the stirred solutions presented very low DOC removal, which may be related with an increase in solubility promoted by the initial $\mathrm{pH}$ correction. A regular increase in $\mathrm{pH}$ during the assays was observed in all the tested experimental conditions, although for the assays performed at initial $\mathrm{pH} 4$ the observed increase was very low. Regarding conductivity, for $\mathrm{AB}$ or UP samples, there was an increase during the treatment, probably due to two different reasons: the correction of the initial $\mathrm{pH}$ and the high energy consumptions, which may allow simultaneously degradation of the organic matter, originating low molecular mass compounds, besides the electrocoagulation/flocculation effect.

In Fig. 1, the specific removals in COD, i.e., COD removed per iron and per energy consumption, for the different assays run with samples L1, are plotted. For the two types of samples, AB and UP, the most economical treatments, either in iron or in energy consumptions, were obtained for the unstirred assays. Identical results of those presented in Fig. 1 for L1 samples are presented in Fig. 2 for the assays run with samples L2 (AB and UP), for almost all the initial $\mathrm{pH}$ and applied potential tested. The specific removals in COD are very dependent on the time necessary to perform the electrocoagulation, i.e., to observe the flocculation, and, in general, the electrocoagulation times increased with stirring. 
For the samples collected after the biological treatment (Fig. 2, a and b), the most economical solution is obtained at $\mathrm{pH} 4$, in the unstirred solution, followed by the assays performed at initial $\mathrm{pH} 10$ with stirring. For these samples, higher energy and iron consuming were obtained at initial $\mathrm{pH}$ of 6 . However, for the UP samples (Fig. 2, c and d), the best results were attained in the unstirred solutions, at initial $\mathrm{pH} 6$.
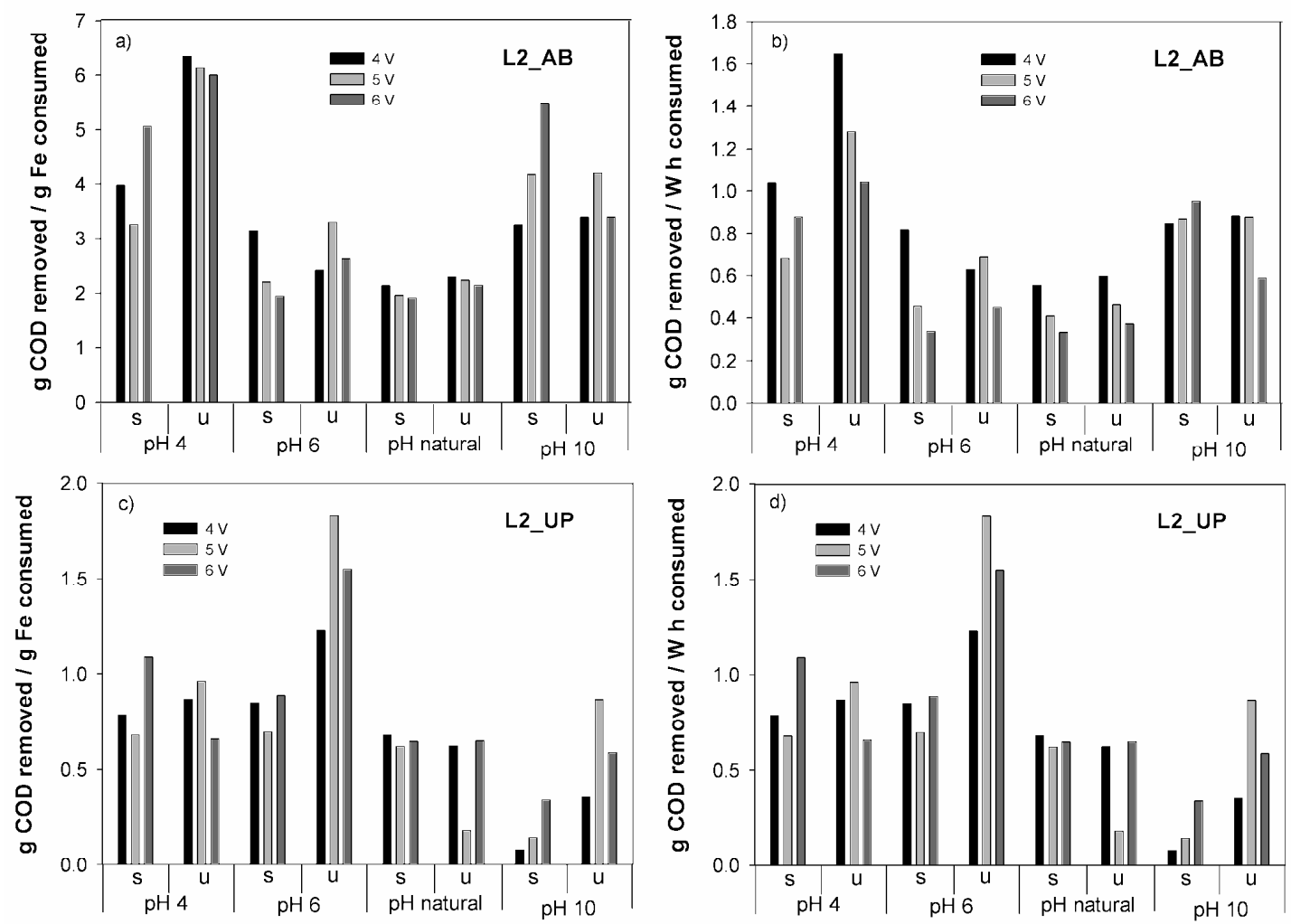

Figure 2. Ratios of COD removed by iron $(a, c)$ and energy $(b, d)$ consumption for the electrocoagulation assays performed with leachate L2, with the samples collected after biological treatment $(\mathrm{AB})$ and in ultrafiltration permeate (UP), at different initial $\mathrm{pH}$ and applied potential.

\section{Anodic oxidation assays}

Table 4 presents a summary of the results obtained after AO assays, performed at different current densities, using the samples $\mathrm{AB}$ and UP with different EC pretreatments: without stirring, at two different initial $\mathrm{pH}$ values, natural $(7.8$ for $\mathrm{AB}$ and 7.4 for UP) and 6 . The table also includes the average current efficiency for the AO experiments, ACE, calculated using the following equation [34]:

$$
\mathrm{ACE}=100 \mathrm{~F} \mathrm{~V}\left(\frac{\mathrm{COD}_{\mathrm{t}}-\mathrm{COD}_{0}}{8 \mathrm{I} \Delta \mathrm{t}}\right)
$$

For the applied current densities, and since the initial COD contents of the samples were high, the degradation process, apart from the final stage of the assays with UP samples, must be controlled by current. To elucidate this, typical mean mass transfer coefficients, $\mathrm{k}_{\mathrm{m}}$, for raw leachate samples were obtained from literature $\left(\mathrm{k}_{\mathrm{m}}=1.75 \times 10^{-5} \mathrm{~m} \mathrm{~s}^{-1}\right.$ [26] or $2.74 \times 10^{-5} \mathrm{~m} \mathrm{~s}^{-1}$ [29]) and used to calculate the critical COD $\left(\mathrm{COD}_{\mathrm{cr}}=\mathrm{j} / 4 \mathrm{Fk}_{\mathrm{m}}[34]\right)$ that, at the applied current 
density, $\mathrm{j}$, of $300 \mathrm{~A} \mathrm{~m}^{-2}$, guarantees current control. The values of $\mathrm{COD}_{\mathrm{cr}}$ thus obtained are 910 and $1420 \mathrm{mg} \mathrm{L}^{-1}$, showing that, in fact, the performed anodic oxidations must have been controlled during most of the assay by current. This way, an increase of COD removal with current intensity was expected, according to Eq. 8 [34]:

$\mathrm{COD}_{\mathrm{t}}=\mathrm{COD}_{0}-\frac{8 \mathrm{I}}{\mathrm{FV}} \mathrm{t}$

where $\mathrm{V}$ is in $\mathrm{m}^{3}$ and COD in $\mathrm{mg} \mathrm{L}^{-1}$.

Table 4. Experimental results for the samples subjected to anodic oxidation with BDD electrodes after a pretreatement by electrocoagulation, with iron anodes.

\begin{tabular}{|c|c|c|c|c|c|c|}
\hline \multicolumn{3}{|l|}{ Sample type } & \multicolumn{2}{|c|}{$\mathbf{A B}$} & \multicolumn{2}{|c|}{ UP } \\
\hline \multirow{2}{*}{\multicolumn{2}{|c|}{ EC pretreatment experimental conditions }} & Initial $\mathrm{pH}$ & 7.8 & 6 & 7 & 6 \\
\hline & & Potential / V & 4 & 5 & 4 & 5 \\
\hline \multicolumn{2}{|c|}{ AO experimental conditions } & \multicolumn{5}{|c|}{$200 \mathrm{~mL} ; 8 \mathrm{~h}$} \\
\hline \multirow{6}{*}{$j=100 \mathrm{~A} \mathrm{~m}^{-2}$} & \multirow{3}{*}{ Removal (AO) / \% } & COD & 46 & -- & 70 & -- \\
\hline & & TOC & 6 & -- & 43 & -- \\
\hline & & Abs $(250 \mathrm{~nm})$ & 51 & -- & 86 & -- \\
\hline & $\mathrm{ACE}(\mathrm{AO}) / \%$ & & 100 & & 75 & \\
\hline & \multirow{2}{*}{ Total removal $(\mathrm{EC}+\mathrm{AO}) / \%$} & COD & 58 & -- & 78 & -- \\
\hline & & TOC & 25 & -- & 53 & -- \\
\hline \multirow{6}{*}{$\mathrm{j}=200 \mathrm{~A} \mathrm{~m}^{-2}$} & \multirow{3}{*}{ Removal (AO) / \% } & COD & 68 & -- & 83 & -- \\
\hline & & TOC & 10 & -- & 61 & -- \\
\hline & & $\operatorname{Abs}(250 \mathrm{~nm})$ & 20 & -- & 90 & -- \\
\hline & $\mathrm{ACE}(\mathrm{AO}) / \%$ & & 100 & & 51 & \\
\hline & \multirow{2}{*}{ Total removal $(\mathrm{EC}+\mathrm{AO}) / \%$} & COD & 75 & -- & 87 & -- \\
\hline & & TOC & 28 & -- & 68 & -- \\
\hline \multirow{6}{*}{$\mathrm{j}=300 \mathrm{~A} \mathrm{~m}^{-2}$} & \multirow{3}{*}{ Removal (AO) / \% } & COD & 75 & 68 & 84 & 98 \\
\hline & & TOC & 38 & 33 & 65 & 65 \\
\hline & & Abs $(250 \mathrm{~nm})$ & 73 & 83 & 93 & 85 \\
\hline & $\mathrm{ACE}(\mathrm{AO}) / \%$ & & 93 & 85 & 35 & 31 \\
\hline & \multirow{2}{*}{ Total removal $(\mathrm{EC}+\mathrm{AO}) / \%$} & COD & 81 & 75 & 88 & 99 \\
\hline & & TOC & 50 & 52 & 80 & 75 \\
\hline
\end{tabular}

Regarding the AO assays of AB and UP samples obtained with the EC treatment at natural $\mathrm{pH}$ (Table 4), COD removals increase with current density. This fact may be related to a decrease in fouling of the BDD. Regarding TOC removal, although it also increases with current density, it presents much lower values than those of COD removal, maybe due to low mineralization of the organic matter. The UP samples presented the best COD and TOC removals and absorbance decay of all the treated samples. This was due probably to the existence of lower molecular weight compounds, which degraded more easily. However, current efficiencies were lower for UP samples treatment, since part of the assay was probably run at diffusion controlled conditions, i.e., at $\mathrm{COD}<\mathrm{COD}_{\mathrm{cr}}$, due to the lower organic load content, when compared to AB samples. 

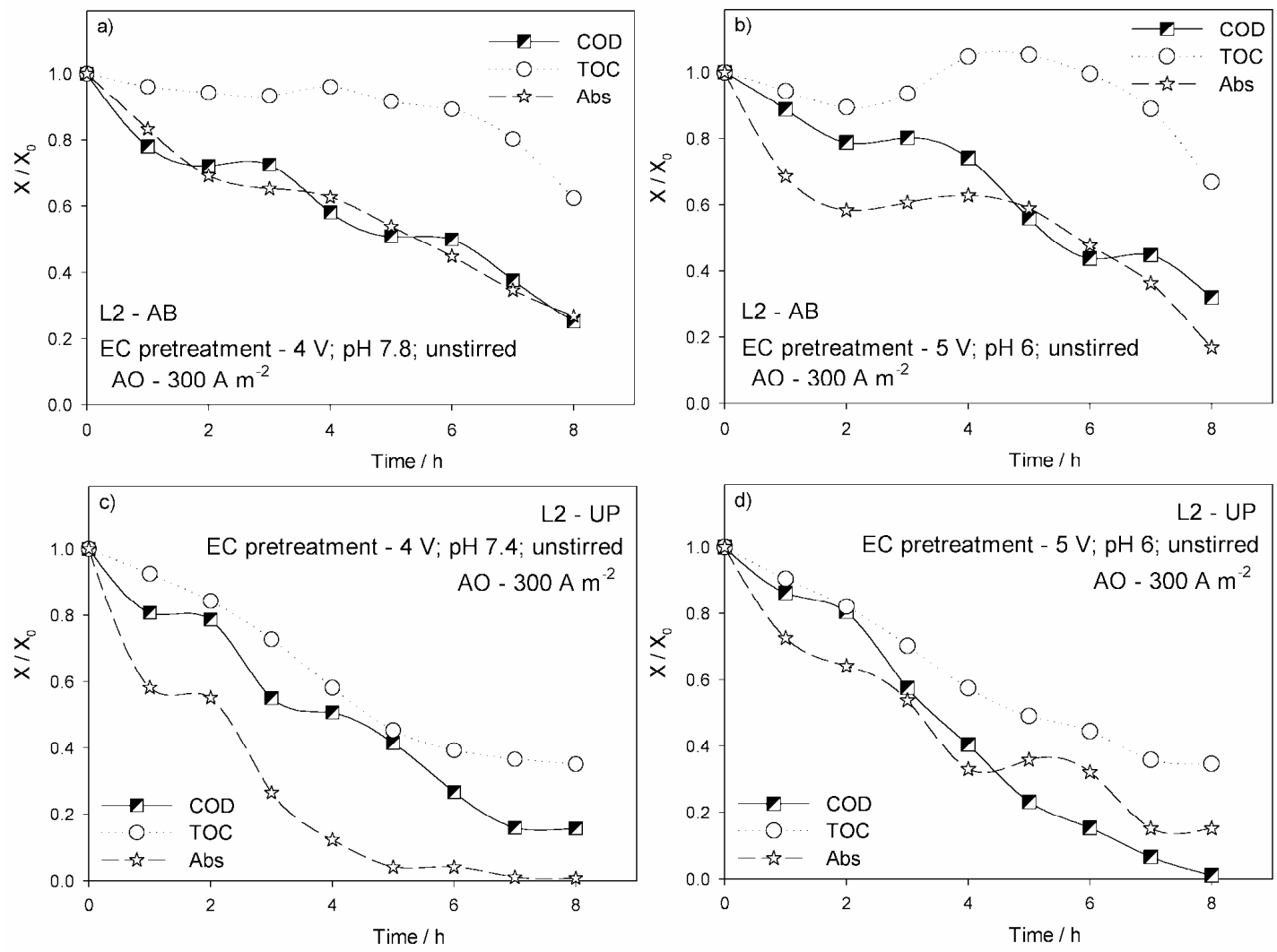

Figure 3. Decays with time of relative COD, TOC and Abs, measured at $250 \mathrm{~nm}$, for the anodic oxidation assays run at $300 \mathrm{~A} \mathrm{~m}^{-2}$, performed with different leachate samples ( $\mathrm{AB}$, and UP) subjected to different unstirred $\mathrm{EC}$ pretreatments: (a) $\mathrm{AB}, 4 \mathrm{~V}, \mathrm{pH} 7.8$; (b) AB, 5 V, pH 6; (c) UP, 4 V, pH 7.4; (d) UP, 5 V, pH 6.

The influence of the EC pretreatment $\mathrm{pH}$ conditions in the AO treatment was also studied for the applied current density of $300 \mathrm{~A} \mathrm{~m}^{-2}$. The results for these assays, also presented in Table 4, show that in the case of AB samples, better COD and TOC removals were obtained in the AO performed with the pretreated EC sample at natural initial $\mathrm{pH}$. Regarding UP samples, the anodic oxidation assays performed with the sample obtained by EC with initial $\mathrm{pH} 6$ gave better removals of COD than those with EC performed at natural $\mathrm{pH}$. However, similar removals in TOC were obtained in both assays. The decays in time of relative COD, TOC and absorbance, measured at $250 \mathrm{~nm}$, for the assays run at $300 \mathrm{~A} \mathrm{~m}^{-2}$ are depicted in Fig. 3. For AB samples (Fig. $3 \mathrm{a}$ and b), the assay run at higher $\mathrm{pH}$ (7.8) shows a more regular decay of all the parameters used to follow the experiment, being the COD decay almost linear with time, typical from a current controlled process. TOC decay presents an initial resistance, indicating that the oxidation process is not leading to higher mineralization degree. On the other hand, in Fig. 3b, it can be observed COD and Abs very irregular decays, by steps, probably due to the presence of different species that were formed during the EC pretreatment at initial $\mathrm{pH}$ of 6 . These assays also show an increase in relative TOC, only possible by the dissolution during the assay of suspended organic solids. Apparently, after the EC pretreatment at $\mathrm{pH}$ of 6 it was left in suspension organic matter with characteristics that present more resistance to the anodic oxidation and, thus, 
lower ACE. In the case of UP samples (Fig. 3c and d), the influence of the EC pretreatment is not very patent, but these samples almost do not have suspended matter and the only fact that prevents them to have a regular COD decay with time is their complexity.

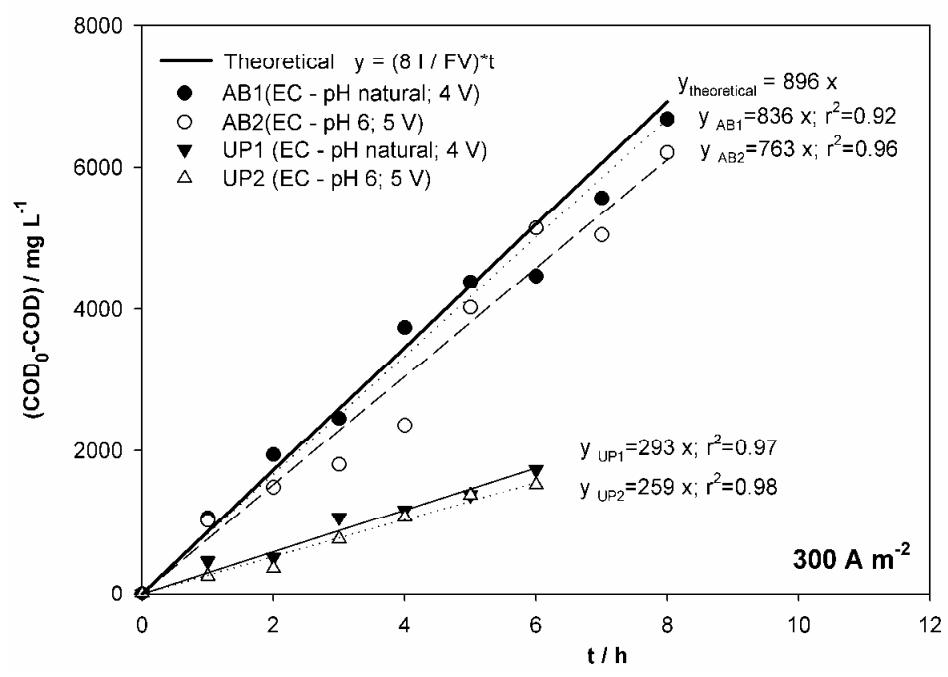

Figure 4. Theoretical COD absolute removals as a function of the elapsed time, for the anodic oxidation assays performed at $300 \mathrm{~A} \mathrm{~m}^{-2}$, and experimental for samples collected in different places of the landfill leachate treatment plant (AB and UP) and submitted to different electrocoagulation pretreatments $(\mathrm{AB} 1$ - natural $\mathrm{pH}, 4 \mathrm{~V} ; \mathrm{AB} 2-\mathrm{pH} 6,5 \mathrm{~V}$; UP1 - natural pH, 4 V; UP2 - pH 6, 5 V).

For current efficiency, the best results were attained for the samples with EC pretreatment at natural initial $\mathrm{pH}$. These results for the applied current density of $300 \mathrm{~A} \mathrm{~m}^{-2}$ are depicted in Fig. 4, where the theoretical slope of Eq. 8 is represented, as well as the experimental values for $\mathrm{COD}_{0}-\mathrm{COD}$ vs. time and the correspondent fits of linear equations to the experimental values, for all the assays performed at that current density. In fact, the assays that follow a similar behaviour to the theoretical one are those performed with $\mathrm{AB}$ samples, especially the $\mathrm{AB}$ sample obtained from the $\mathrm{EC}$ treatment at initial natural $\mathrm{pH}$. In the case of UP samples, the experimental results are very different from the theoretical ones, probably because relative mineral content is higher and also due to the fact that part of the assay must have been run in diffusion control, thus decreasing current efficiency and leading to a COD abatement inferior to the expected.

\section{Conclusions}

According to the obtained results, the application of combined electrochemical techniques, namely electrocoagulation and anodic oxidation, seems an option as polishing treatment of leachates from sanitary landfills. In fact, in the combined treatment, $\mathrm{COD}$ removals for $\mathrm{AB}$ samples were always higher than $75 \%$, leading easily to final samples with lower COD than those collected in the ultrafiltration permeate (UP samples). 
Regarding the electrocoagulation assays, the best specific COD removals per iron or per energy consumptions were obtained at $\mathrm{pH} 4$, in the unstirred solution, for $\mathrm{AB}$ samples, and at initial $\mathrm{pH} 6$, in the unstirred solutions, for UP samples. In general, the use of stirring increases the time needed to start, with a visible rate, the precipitation of the flocs formed in the electrocoagulation. On the other hand, the electrocoagulation time is reduced by an increase in the applied potential, due to a higher rate of iron oxidation.

For the electrocoagulation treatments performed at natural initial $\mathrm{pH}$, seasonality does not seem to have a big impact on the iron consumption for $\mathrm{AB}$ samples. However, for the assays performed with $\mathrm{AB}$ samples, at natural $\mathrm{pH}, \mathrm{COD}$ removal per iron or energy consumption is higher in the case of L2 samples when compared with L1 samples. Apparently, the dilution effect due to rain season increases the efficiency of the EC process.

In the combined treatment, the highest average current efficiencies were obtained for the samples collected at the landfill leachate treatment plant after the biological treatment, being more relevant for the assay performed with the following experimental conditions: electrocoagulation at $4 \mathrm{~V}$, with natural initial $\mathrm{pH}$, without stirring, followed by anodic oxidation at $300 \mathrm{~A} \mathrm{~m}^{-2}$.

In the combined treatment, the best results were attained for the highest applied current density and, for all types of samples tested, it was observed that total COD removal is influenced by the type of electrocoagulation pretreatment.

\section{Acknowledgements}

Financial support from FEDER, through Programa Operacional Factores de Competitividade - COMPETE, and FCT, for the project PTDC/AACAMB/103112/2008, and for the grant awarded to A. Fernandes, SFRH/BD/81368/2011, are gratefully acknowledged.

\section{References}

1. Kjeldsen P, Barlaz MA, Rooker AP, Baun A, Ledin A, Christense TH. Crit Rev Env SciTec. 2002;32:297-336.

2. Alkalay D, Guerrero L, Lema JM, Mendez R, R. Chamy R. World J Microb Biot. 1998;14:309-320.

3. Öman CB, Junestedt C. Waste Manage. 2008;28:1876-1891.

4. Eggen T, Moeder M, Arukwe A. Sci Total Environ. 2010;408:5147-5157.

5. Aziz SQ, Aziz HA, Yusoff MS, Bashir MJK, Umar M. J Environ Manage. 2010;91:2608-2614.

6. Renou S, Givaudan JG, Poulain S, Dirassouyan F, Mouli P. J Hazard Mater. 2008; 150:468-493.

7. Zhao G, Pang Y, Liu L, Gao J, Lv Ba. J Hazard Mater. 2010;179:10781083.

8. Chianese A, Ranauro R, Verdone N. Water Res. 1999;33:647-652.

9. Feki F, Aloui F, Feki M, Sayadi S. Chemosphere. 2009;75:256-260.

10. Chaudhari LB, Murthy ZVP. J Environ Manage. 2010;91:1209-1217. 
11. Liu $\mathrm{H}$, Zhao $\mathrm{X}, \mathrm{Qu}$ J. Electrocoagulation in water treatment. In: Comninellis C, Chen G, editors. Electrochemistry for the environment. New York. Springer Science+Business Media, LLC; 2010. Chapter 10; p. 245262.

12. Chen G., Sep Purif Technol. 2004;38:11-41.

13. Mollah MYA, Schennach R, Parga JR, Cocke DL. J Hazard Mater. 2001;B84:29-41.

14. Tsai CT, Lin ST, Shue YC, Su PL. Water Res. 1997;31:3073-3081.

15. Ilhan F, Kurt U, Apaydin O, Gonullu MT. J Hazard Mater. 2008;154:381389.

16. Lei Y, Shen Z, Huang R, Wang W. Water Res. 2007;41:2417-2426.

17. Cossu R, Polcaro AM, Lavagnolo MC, Mascia M, Palmas S, Renoldi F. Environ Sci Technol. 1998;32:3570-3573.

18. Panizza M, Delucchi M, Sirés I. J Appl. Electrochem. 2010;40:1721-1727.

19. Turro E, Giannis A, Cossu R, Gidarakos E, Mantzavinos D, Katsaounis A. J Hazard Mater. 2011;190:460-465.

20. Zhao X, Qu J, Liu H, Wang C, Xiao S, Liu R, Liu P, Lan H, Hu C. Bioresource Technol. 2010;101:865-869.

21. Cabeza A, Primo O, Urtiaga AM, Ortiz I. Separ Sci Technol. 2007;42:1585-1596.

22. Urtiaga A, Rueda A, Anglada A, Ortiz I. J Hazard Mater. 2009;166:15301534.

23. Anglada A, Ortiz D, Urtiaga AM, Ortiz I. Water Sci Technol. 2010;61:2211- 2017.

24. Anglada A, Urtiaga A, Ortiz I. Environ Sci Technol. 2009;43:2035-2040.

25. Anglada A, Urtiaga A, Ortiz I. J Hazard Mater. 2010;181:729-735.

26. Anglada A, Urtiaga A, Ortiz I, Mantzavinos D, Diamadopoulos E. Water Res. 2011;45:828-838.

27. Cabeza A, Urtiaga AM, Ortiz I. Ind Eng Chem Res. 2007;46:1439-1446.

28. Cabeza A, Urtiaga A, Rivero MJ, Ortiz I. J. Hazard. Mater. 2007;144:715719.

29. Fernandes A, Pacheco MJ, Ciriaco L, Lopes A. J Hazard Mater. 2010;199200:82-87.

30. Deng Y, Englehardt JD. Waste Manage. 2007;27:380-388.

31. Anglada A, Urtiaga A, Ortiz I. J Chem Technol Biotechnol. 2009;84:17471755.

32. Ghernaout D, Naceura MW, Aouabeda A. Desalination 2011;270:9-22.

33. Ihara I, Kanamura K, Shimada E, Watanabe T. IEEE T Appl Supercon. 2004;14:1558.

34. Comninellis C, Pulgarin C. J App. Electrochem. 1991;21:703-708. 